\title{
ПРАВОВА ПОЛІТИКА У СФЕРІ ІННОВАЦІЙ ТА ІНТЕЛЕКТУАЛЬНОЇ ВЛАСНОСТІ
}

\author{
МАЛЕЦЬ Марта Романівна - асистент кафедри адміністративного та \\ інформаційного права Навчально-наукового інституту права, психології та \\ інноваційної освіти Національного університету «Львівська політехніка» \\ DOI 10.32782/EP.2020.3.8
}

В статье исследуется правовая политика в сбере инноваций и интеллектуальной собственности. Обоснована необходимость инновачионного развития Украинъ как одного из главнъгх фбакторов социально-якономического развития. Проанализированъ подходъ к определению сушности категории инновачионная деятельность и определенъ проблемъ правового регулирования инновационной деятельности в контексте с интеллектуальной деятельностью при обеспечении инновационного развития странъ $u$ регионов. Уточнена сушность правовой политики по активизации и развития инновационной составляющей нащиональной якономики. Проанализировано содержание основных нормативных документов по осуществлению инновационной деятельности на предмет наличия правовых мотивачионнъгх инструментов активизации.

Ключевъе слова: правовая политика, инноваџия, инновационная деятельность, интеллектуальная собственность, инновациионое развитие, правовое регулирование.

\section{Постановка проблеми}

В умовах європейської інтеграції та інформаційного суспільства, що формується, увага вчених, які є представниками різних галузей наукового знання, приділяється інноваціям як матеріалізованим результатам інтелектуальної діяльності. Під інноваційною діяльністю розуміється сукупність взаємопов'язаних дій зі створення, освоєння та поширення інновацій, яка складається 3 низки послідовних стадій, регулюеться різними нормами права: цивільного, адміністративного, фінансового, податкового, трудового та інших галузей національної системи права. Виходячи з цього, інноваційна діяльність складає міжгалузевий комплексний інститут.

\section{Стан дослідження}

Загальні та окремі питання правової політики у сфері інновацій та інтелектуальної власності розглядали в працях учені: В. Б. Авер'янов, В. М. Бевзенко, А. А. Борко, М. Г. Вербенський, К. Ф. Гуценко, І. В. Зозуля, Н. В. Камінська, Т.О. Коломоєць, В. К. Колпаков, А. Т. Комзюк, К. Б. Аевченко, В. Я. Малиновський, Р. С. Мельник, О. І. Миколенко, І. І. Сидорук, В. А. Синчук, О. Ю. Синявська, О. А. Соколенко, С. Г. Стеценко, Ю. С. Шемшученко та ін. Ці вчені зробили значний вклад у розвиток проблем правового регулювання у контексті адміністративного права. Aле в умовах адаптації національного законодавство до вимог Европейського Союзу низка питань зазначеної теми залишається дискусійною.

Мета статті - дослідження правової політики у сфері інновацій та інтелектуальної власності.

Виклад основного матеріалу

Ефективна інноваційна діяльність є одним 3 пріоритетних напрямів розви- 
тку держави. Таке твердження підтверджують прийняті програмні документи щодо розвитку інноваційного середовища в державі. Правова політика у сфері інновацій - це складова державної науковотехнічної та промислової політики, метою якої є формування економічних умов для виведення на ринок конкурентоспроможної інноваційної продукції.

Інноваційна політика виступає складовою соціально-економічної та правової політики, спрямована на стимулювання інтелектуальної діяльності, створює передумови для ефективного розвитку інноваційної системи держави. Право є інструментом регулювання суспільних, зокрема економічних відносин. Ефективність права в регулюванні економічних відносин залежить і від того, наскільки повно відображає економічні потреби суспільства.

Державна інноваційна політика значною мірою складається 3 різноманітних планів, стратегій і програм. Таке положення пояснюється тим, що правове регулювання інноваційної діяльності грунтується швидше на моделюванні майбутніх суспільних відносин, ніж закріплює вже сформовані відносини. Зазначена особливість цього виду правовідносин визначає більш тісний зв'язок правового регулювання та правової політики саме у сфері інтелектуальної діяльності та інновацій.

У літературі під правовою політикою у сфері інновацій розуміють науково обгрунтовану, послідовну, системну діяльність державних і недержавних структур, спрямовану на визначення тактики та стратегії правотворчості у сфері інновацій, створення соціально-правової інфраструктури реалізації інтелектуальних прав громадян і організацій, формування у наукових і юридичних кадрів спеціальних правових компетенцій, що відповідають запитам інноваційного розвитку.

Правова політика у сфері інновацій покликана поєднувати публічно-правові та приватноправові інтереси, може бути виражена у таких формах: правотворча політика; політика реалізації права; політика інтерпретації права; політика правової освіти; правоохоронна та правозахисна політика.

Правотворча політика у сфері інновацій - це науково обгрунтована, послідовна та системна діяльність органів державної влади, органів місцевого самоврядування, інститутів громадянського суспільства щодо створення необхідних правових умов для ефективної інноваційної діяльності шляхом розробки і прийняття нормативної бази у галузі інноваційного розвитку.

Політика реалізації права у сфері інновацій становить науково обгрунтовану, послідовну та системну діяльність органів державної влади та місцевого самоврядування, недержавних структур зі створення правової інфраструктури з метою реалізації інтелектуальних прав.

Політика інтерпретації права у сфері інновацій складає науково обгрунтовану, послідовну, системну діяльність. органів державної влади та місцевого самоврядування, недержавних структур щодо тлумачення чинного законодавства у сфері інновацій й охорони та захисту об'єктів інтелектуальної власності.

Політика правової освіти у сфері інновацій становить науково обгрунтовану, послідовну, системну діяльність органів державної влади та місцевого самоврядування, недержавних структур щодо створення умов для підвищення якісного складу наукових i науково-педагогічних працівників, стимулювання припливу молоді в науку.

Правоохоронна політика в сфері інновацій спрямована на створення єдиного правового поля $з$ охорони прав і законних інтересів суб'єктів інтелектуальної та інноваційної діяльності здійснюється завдяки впорядкованим діям уповноважених органів 3 виявлення або розслідування правопорушень, відновлення порушених прав, захисту правопорядку, наглядом за додержанням законності, активною і цілеспрямованою взаємодією [1, с. 150].

Під правозахисною політикою розуміють науково обгрунтовану, послідовну та комплексну діяльність державних і недержавних структур щодо оптимізації захис- 
ту прав людини, вдосконалення засобів і способів захисту, формування повноцінної правозахисної системи.

Нині загальновизнаними є два базові підходи до визначення поняття інновація. У широкому сенсі під інновацією розуміється результат творчої діяльності, застосування якого призводить до істотних змін у функціонуванні системи.

У вузькому сенсі інновація - це нове рішення технічного завдання, здійснене в практичній діяльності. Ознаками інновацій виступають: новизна, сукупність властивостей, що свідчать про кардинальні зміни об'єкта, внаслідок яких задовольняється нова потреба або задовольняється по-новому наявна потреба, знижуються витрати тощо; спрямованість на конкретне перетворення, мають на увазі не різноманітні незв'язані нововведення, що виникають миттєво під впливом подій, а тільки ті, які мають на меті конкретне перетворення; зв’язок з інтелектуальною діяльністю, тобто інновації є результатом науково-дослідної або іншої інтелектуальної діяльності; виробнича застосовність, можливість і здатність застосування інновації і отримання на їі основі нового або вдосконаленого продукту; комерційна реалізація, тобто задоволення споживчого попиту, наявного на ринку, інакше кажучи, важливою ознакою інновацій $\epsilon$ можливість комерціалізації інноваційного продукту, його залучення в економічний обіг з метою отримання прибутку; отримання економічної вигоди або створення умов для її отримання; ефективність, спрямованість на вдосконалення процесу виробництва.

У контексті Закону України «Про інноваційну діяльність» інновації - це новостворені (застосовані) і (або) вдосконалені конкурентоздатні технології, продукція або послуги, а також організаційно-технічні рішення виробничого, адміністративного, комерційного або іншого характеру, що істотно поліпшують структуру та якість виробництва і (або) соціальної сфери [2]. Інновацію варто розглядати у вигляді родового поняття, що об'єднує охоронювані результати інтелектуальної діяльності, які виникають у результаті створення нововведень, нових технічних рішень, коли вони виражені в об'єктивній формі і можуть задовольняти суспільні потреби.

Під інновацією варто розуміти результат інтелектуальної праці, що одержав втілення у вигляді нового або вдосконаленого продукту (товару, робіт, послуг), технічного процесу, який володіє комерційним потенціалом.

С. Г. Гордієнко і О. В. Соснін, розглядаючи сутність, зміст, практику інноваційної діяльності та захисту інтелектуальної власності в Україні, зазначають, що інноваційна діяльність є підставою створення нового знання та інтелектуальних продуктів, визнаних на державному, регіональному та світовому рівнях, на які поширюється право власності [3, с. 245].

Інноваційною діяльністю є виконання робіт і (або) надання послуг, спрямованих на створення і організацію виробництва принципово нової або з новими споживчими властивостями продукції (товарів, робіт, послуг), 3 одного боку. 3 іншого боку, інноваційна діяльність - це створення нових або модернізація існуючих способів (технологій) виробництва продукції, іiі поширення та використання.

у сучасних джерелах виділяють такі основні юридично значимі ознаки інновацій: $є$ результат наукової творчості, як правило, у вигляді об'єкта інтелектуальної власності; виступає у вигляді продукту, технології, послуги, інших матеріальних форм, здатних до відтворення; призначена для задоволення потреб суспільства. Водночас інноваційна діяльність вимагає осмислення основних понять і законів економіки.

Характерною особливістю розвитку наукового знання $є$ створення своєрідного поля перетину, активної взаємодії і взаємопроникнення різних наук, теоретичних концепцій і методів пізнання, що збагачуе їх і приносить виключно плідні результати.

ภегітимне визначення того, яку діяльність необхідно вважати інноваційною, подано в Законі України «Про інновацій- 
ну діяльність». У літературі класифікують інновації за різними підставами, виділяючи різноманітні види інновацій. Продуктовими інноваціями виступає новий або істотно поліпшений продукт. Процесними інноваціями є впровадження технологічно нових процесів виробництва або їх вдосконалення. Маркетингові інновації - це впровадження нового методу маркетингу. Організаційні інновації - це впровадження нових організаційних методів.

За рівнем новизни виділяють такі види інновацій: базисні інновації і поліпшуючі інновації. Базисні інновації є нововведення, засновані на докорінній зміні, на фундаментальних науково-технічних результатах, спрямовані на впровадження принципово нових технологій. Поліпшені інновації виражаються у створенні нових матеріалів і машин, вони спрямовані на поліпшення параметрів продукції, що випускається, послуг, що надаються, технологій, що використовуються.

О. В. Захарова та I. С. Барбанов під інноваційною діяльністю розуміють сукупність скоординованих дій, робіт і послуг зі створення і практичного використання нової або удосконаленої продукції або нового або вдосконаленого процесу [4, с. 56].

Інноваційна діяльність складається 3 таких стадій технологічної реалізації: розробка фундаментального наукового знання; створення прикладного наукового знання; застосування отриманого наукового знання для створення зразка результату інноваційної діяльності; закріплення прав на результат інтелектуальної власності; впровадження результату інноваційної діяльності у виробництво; комерціалізація результату інноваційної діяльності та отримання прибутку.

Правова політика у сфері інновацій має бути спрямована та всіляко сприяти створенню i впровадженню інновацій у державі, стимулювати інноваційну та інтелектуальну діяльність. Результатом такої інноваційної політики повинні виступати нові явища соціальної дійсності, такі як: технопарки, технополіси, бізнес-інкубатори, особливі економічні зони, територі- ально-галузеві виробничі кластери, інші об'єкти інноваційної інфраструктури.

Необхідно зазначити, що технополіси набули достатнього поширення в розвинених країнах Європейського Союзу та в Японії, причому відбувається подальший поступальний розвиток. В Україні проголошено прагнення держави до всебічного розвитку інновацій, державну підтримку різних форм стимулювання творчої діяльності, мінімізація сировинної залежності. Стратегія розвитку сфери інноваційної діяльності на період до 2030 року визначає курс на інноваційний розвиток як пріоритетний напрям розвитку України [5].

Правова політика держави в цілях всебічного розвитку інноваційної діяльності може включати низку стимулів, зокрема, фінансово-правові стимули: фіскальні пільги, пов'язані з податковим стимулюванням; спеціальний пільговий субсидіарний режим гарантії від несприятливої зміни законодавства про податки та збори; бюджетні асигнування; ефективний доступ до фінансових ресурсів; інвестиційний податковий кредит.

Дуже важливим моментом є необхідність створення сприятливих умов у державі для залучення інвестицій. Особлива роль тут належить інфраструктурі інновацій, передусім, венчурним інвестиційним фондам. Необхідно створити такі умови, при яких базові фундаментальні дослідження проводилися не стільки за рахунок бюджетного фінансування, а більшою мірою за рахунок приватних інвестицій, великих корпорацій, виробників і споживачів наукомісткої продукції. Для ефективної реалізації такого приватно-державного партнерства необхідно створювати спеціальні програми прямого співробітництва держави та приватного бізнесу.

Метою державної інноваційної політики має стати створення умов для сталого економічного зростання, виходу інноваційної продукції на внутрішній і зовнішній ринки за рахунок підвищення технологічного рівня та конкурентоспроможності виробництва.

Юридичними підставами правової політики у сфері інновацій виступають між- 
народні та внутрішньодержавні нормативно-правові акти, що регламентують питання здійснення інноваційної діяльності та окремі правозастосовні акти.

В Україні правова основа інноваційної діяльності базується на Законі «Про інноваційну діяльність». Але відсутній системний підхід щодо взаємного доповнення нормативно-правового регулювання у сфері інноваційної й інтелектуальної діяльності. На нашу думку, відсутні не просто будь-які нормативно-правові акти, немає системності підходу, розуміння сутності та структури предмета правового регулювання, всеосяжного охоплення організованих відносин. У зв'язку з цим, становлення правової політики України у сфері інновацій у контексті охорони та захисту інтелектуальної власності відбувається в умовах недостатньо сформованої нормативно-правової бази.

Законодавчий масив про інноваційну діяльність виглядає як самостійний правовий блок, практично не пов'язаний 3 сучасними і цілком усталеними в системі права інтелектуальної власності утвореннями. Курс на інноваційний розвиток України як важливий напрям правової політики держави закріплюється в Цілях сталого розвитку України на період до 2030 року як моделі розвитку держави [6].

Для досягнення зазначених цілей необхідно вдосконалення нормативно-правової бази, на її основі, створення ефективного механізму реалізації конституційно закріпленого права громадян на творчу діяльність.

Необхідно внести зміни та доповнення до цілої низки законодавчих актів 3 метою узгодження, розробити тезаурус у сфері інноваційної діяльності. Слід створити комплекс нормативно-правової бази, який враховував би всі правовідносини, які можуть потенційно виникнути при здійсненні інноваційної діяльності.

Державна політика в інноваційній сфері заснована на державних стратегіях i програмах розвитку в різних галузях у рамках єдиної правової політики у сфері інновацій. Правова політика у сфері інновацій встановлюе цілі та пріоритети суспільного розвитку, визначає сучасне становище питання, сучасні проблеми та подальші перспективи вдосконалення інноваційного потенціалу країни.

Потрібний комплексний, системний підхід до формування інноваційного середовища і інноваційної інфраструктури, до ефективного державного управління інноваційною системою як результат, широка інтеграція у світове конкурентне середовище. Для досягнення зазначених орієнтирів і реалізації заявлених завдань необхідне прийняття цілого ряду політичних і правових актів. Важливим 6 створення життєздатної системи органів державного та місцевого рівнів $з$ певними завданнями та повноваженнями в інноваційній сфері.

Державна інноваційна політика повинна формуватися, виходячи 3 цілей не тільки організації та розвитку, а й заохочення творців інноваційної продукції. Правову політику держави у сфері інновацій слід визначати як складову частину державної науково-технічної та промислової політики, як сукупність здійснюваних соціальних, економічних і інших заходів. Зазначені заходи повинні бути спрямовані на формування умов для всебічного розвитку виробництва конкурентоспроможної інноваційної продукції на базі передових досягнень науки та техніки.

Заходи повинні сприяти підвищенню частки такої продукції, так само як створення системи просування та реалізації інноваційної продукції та послуг на європейському економічному просторі, на світовому ринку. Правова політика у сфері інновацій України значною мірою за змістом складається з різноманітних проектів, різного рівня планів і прогнозів перспективного розвитку.

Базові основи, що визначають цілі та пріоритети правової політики у сфері інновацій, містяться в політико-правових документах - концепціях або стратегіях. Цілями та пріоритетами державної правової політики у сфері інновацій є всебічний розвиток інноваційної системи, формування механізму інноваційного розвитку регіонів, підвищення конкурентоспромож- 
ності суб'єктів інноваційної діяльності, зростання обсягів інноваційної продукції.

Слід враховувати нагальну потребу створення сприятливого клімату та підтримки учасникам інноваційної діяльності, науково-технічної творчості, розвиток освітніх програм, системи підвищення кваліфікації фахівців 3 інтелектуальної власності, освоєння практичних навичок ведення підприємницької і іншої господарської діяльності в інноваційній сфері.

Говорячи про державні стратегії та програми розвитку в рамках правової політики в інноваційній сфері, важливо відзначити, що формування ефективної національної інноваційної системи виступає одним із пріоритетних напрямів державної політики України.

Стратегії та програми розвитку у галузі інтелектуальної власності в інтересах технологічного ринку України визначають цілі та пріоритети державної політики у сфері інтелектуальної власності, встановлює довгострокові орієнтири розвитку національної системи інтелектуальної власності. Цілями зазначених стратегічних планів заявлені розробка комплексу правових, організаційно-економічних та інституційних механізмів у галузі інтелектуальної власності, розвиток промислового наукоємного виробництва, примноження науково-технічного потенціалу країни, створення та введення в цивільний обіг конкурентоспроможної інноваційної і високотехнологічної продукції, формування сприятливого економічного клімату, розвиток інноваційних підходів..

У їх основі містяться положення Стратегії розвитку сфери інноваційної діяльності на період до 2030 року, Цілей сталого розвитку України на період до 2030, рекомендацій Всесвітньої організації інтелектуальної власності щодо формування національних стратегій у галузі інтелектуальної власності та рекомендацій Парламентських слухань на тему «Побудова ефективної системи охорони інтелектуальної власності в Україні» [7].

Досліджуючи проблеми та завдання освіти $з$ інтелектуальної власності у системі вищої освіти України, О.П.Орлюк за- значає, що державна програма розвитку освіти передбачає організацію підготовки нового покоління управлінських кадрів у сфері інтелектуальної власності в провідних міжнародних університетах і стажування фахівців в патентних відомствах країн Европейського Союзу [8, с. 150].

Пріоритетним напрямом інноваційного розвитку є створення умов для формування здатності до творчого, критичного мислення, підприємливості, креативності, наявності навичок i вміння ефективно працювати в творчому середовищі. Важливо сформувати правову культуру у сфері інтелектуальної власності, здатність до ділового та професійного спілкування у сфері інноваційного розвитку. 3 розвитком науково-технічного прогресу суспільні відносини вступають у нову сферу, в Інтернет, який впливає на всі аспекти соціального життя. По суті, народжується новий вид цивілізаційних відносин, який трансформує звичний уклад: змінюеться зміст праці, істотні перетворення відбуваються в культурі й освіті [9, с. 150].

До пріоритетних напрямів інноваційного розвитку відноситься: створення системи заохочень і гнучких регуляторів з метою вдосконалення механізму, що дозволяє здійснювати фінансову, організаційну та консультаційну підтримку ефективних результатів інноваційної діяльності на всіх стадіях життевого циклу; активізація підтримки виходу на зовнішні ринки інноваційних високотехнологічних компаній; удосконалення нормативно-правової бази у сфері інноваційної діяльності; створення системи центрів колективного користування у сфері творчих індустрій, формування відкритої інформаційної системи моніторингу якості надання адміністративних послуг у галузі інтелектуальної власності та інновацій; розробка та реалізація програм розвитку регіональної інноваційної інфраструктури, впровадження нових технологій i формування територіальних структур.

Сучасний стан в інноваційній сфері характеризується збереженням застійних тенденцій i невиправданого адміністрування, з одного боку, з іншого, в останні 
роки країна втратила позиції лідера в інтелектуальній сфері, що дозволяє зробити висновок про низьку ефективність національної системи у сфері інновацій та назрілу необхідність у реформуванні. Особливостями завтрашньої системи державного управління повинні стати самостійність і відповідальність, динамічний рух вперед, проходження загальної ідеології європейської інтеграції країни, ефективне використання ресурсів, неординарні рішення, підтримка ініціативи та інновацій, змінюваність кадрів, компетентність.

\section{Висновки}

Державні стратегії та програми розвитку інновацій повинні грунтуватися на перспективній правовій політиці в цій галузі, визначати цілі і пріоритети розвитку, стимулювати розвиток i впровадження інноваційних технологій. 3 метою дослідження юридичних аспектів інноваційних явищ і процесів, у літературі пропонується виробляти відповідний категоріальний апарат. Заявлена потреба в чіткому визначенні таких понять: інноваційні явища, інноваційна діяльність та ряд інших. Інноваційні явища слід розуміти як кінцевий результат успішного впровадження нових елементів, змін форми якоїсь системи 3 метою підвищення ㄲï ефективності та оптимального вирішення нагальних соціально значущих завдань. Інноваційна діяльність є істотне нововведення, докорінна модернізація певних галузей життєдіяльності суспільства, спрямованих на підвищення дієвості та значне збільшення цінності управлінських систем.

Під правовою політикою у сфері інновацій пропонується розуміти науково обгрунтовану, послідовну, системну та злагоджену роботу державних структур i інститутів громадянського суспільства, спрямовану на формування правових передумов для ефективної інноваційної діяльності шляхом прийняття відповідних нормативно-правових актів, вибудовування дієвого механізму правозастосування в галузі охорони і захисту інтелектуальної власності, підготовки кваліфікованих кадрів для роботи в інноваційній сфері.
Правова політика в сфері інновацій має бути націлена на правове забезпечення всебічного інноваційного розвитку країни в рамках єдиної стратегії та тактики, що включає закони, стратегічні плани та концепцій розвитку. Це пояснюється тим, що правове регулювання інноваційної діяльності грунтується на моделюванні майбутніх суспільних відносин і направлено на стимулювання інтелектуальної діяльності у всіх сферах життєдіяльності держави.

\section{Література}

1. Ковалів М. В., Єсімов С. С., Лозинський Ю. Р. Правове регулювання правоохоронної діяльності: навчальний посібник. Аьвів: ЛьвДУВС, 2018. 323 с.

2. Про інноваційну діяльність: Закон України від 04.07.2002 р. № 40-IV. Відомості Верховної Ради Украӥни. 2002. № 36. Ciт. 266.

3. Інформаційне суспільство в світі та Україні: проблеми становлення та закономірності розвитку: колективна монограбія. Запоріжжя: ЗДІА, 2017. 282 с.

4. Захарова О. В., Барбанова I. С. Нормативне підгрунтя активізації інноваційного розвитку регіонів України. Економіка і організачія управління. 2019. № 1 (33). C.53-63.

5. Про схвалення Стратегії розвитку сфери інноваційної діяльності на період до 2030 року: Розпорядження Кабінету Міністрів України від 10.07.2019 р.№ 526-p. URL: https://zakon.rada.gov.ua/ laws/show/526-2019-\%D1\%80

6. Про Цілі сталого розвитку України на період до 2030 року: Указ Президента України від 30.09.2019. р. № 722/2019. URL: $\quad$ https://zakon.rada.gov.ua/laws/ show/722/2019

7. Парламентські слухання на тему: «Побудова ефективної системи охорони інтелектуальної власності в Україні». Верховна рада України. URL: https://rada.gov. ua/news/Novyny/186120.html

8. Орлюк О. П. Освіта з інтелектуальної власності у системі вищої освіти України: проблеми та завдання. Теорія $i$ практика інтелектуальної власності. 2019 № 6. C. 148-159. 


\section{АНОТАЦІЯ}

у статті досліджується правова політика у сфері інновацій та інтелектуальної власності. Обгрунтовано необхідність інновачійного розвитку Украӥни як одного з головних чинників сочіально-економічного розвитку. Проаналізовано підходи до визначення сутності категорій інновачійна діяльність та визначено проблеми правового регулювання інноваційної дебільності у контексті з інтелектуальною діяльністю при забезпеченні інноваційного розвитку країни та регіонів. Уточнено сутність правової політики щодо активізащиї та розвитку інноващійной складової національної економіки. Проаналізовано зміст основних нормативних документів щодо здійснення інновачійної діяльності на предмет наявності правових мотиваиійних інструментів активізації.

Ключові слова: правова політика, інновація, інновачійна діяльність, інтелектуальна власність, інноваційний розвиток, правове регулювання.

9. Бортник Н., Есімов С. Відносини в мережі Інтернет як об'єкт правового регулювання. Вісник Національного університету «Аьвівсъка політехніка». Юридичні науки. 2019. Випуск 6. № 22. С. 147-153.
The article explores the legal policy of innovation and intellectual property. The necessity of innovative development of Ukraine as one of the main factors of socio-economic development is substantiated. The approaches to defining the essence of the category of innovative activity are analyzed and the problems of legal regulation of innovative deliberation in the context of intellectual activity while ensuring the innovative development of the country and regions are identified. The essence of the legal policy concerning the activation and development of the innovative component of the national economy has been clarified. The content of the main normative documents on the implementation of innovative activity for the presence of legal motivational tools of activation is analyzed. The main motivational tools that can be used to improve the effectiveness of the current legislation are systematized. It is emphasized that the enhancement of the legal culture regarding intellectual property rights, protection of intellectual property rights can be ensured in the process of innovation. The directions of legal policy aimed at activation of innovative development through the development of protection and protection of intellectual property as a component of innovative activity are outlined.

It is noted that effective innovation is one of the priority areas of state development. This statement is confirmed by the adopted program documents on the development of the innovation environment in the country. Legal policy in the field of innovation is a component of the state scientific, technical and industrial policy, the purpose of which is to create economic conditions for bringing competitive innovative products to the market.

It is emphasized that innovation policy is a component of socio-economic and legal policy aimed at stimulating intellectual activity, creates preconditions for the effective development of the innovation system of the state. Law is an instrument of regulation of social, in particular economic relations. The effectiveness of law in regulating economic relations also depends on how fully it reflects the economic needs of society.

It is established that the state innovation policy largely consists of various plans, strategies and programs. This situation is explained by the fact that the legal regulation of innovation is based on modeling future social relations rather than consolidating already established relations. This feature of this type of legal relationship determines the closer connection between legal regulation and legal policy in the field of intellectual activity and innovation.

Key words: legal policy, innovation, innovative activity, intellectual property, innovative development, legal regulation. 